\title{
Effects of feed particle size on energy values for broiler chickens at various ages
}

\author{
R. Frank ${ }^{1}$, P.C. Pozza ${ }^{2}$, C. Scherer ${ }^{1}$, R.A. Schöne ${ }^{1}$, A.S. Avila ${ }^{1 \#, ~ P . L . O . ~ C a r v a l h o ㄹ, ~ J . ~ B r o c h ~}{ }^{1}$, C. \\ Eyng $^{1}$ \& R.V. Nunes ${ }^{1}$ \\ ${ }^{1}$ Western Parana State University, Marechal Cândido Rondon, Brazil \\ ${ }^{2}$ State University of Maringá, Maringá, Brazil
}

(Submitted 16 April 2020; Accepted 28 July 2020; Published 7 December 2020)

\begin{abstract}
Copyright resides with the authors in terms of the Creative Commons Attribution 4.0 South African Licence.
See: http://creativecommons.org/licenses/by/4.0/za

Condition of use: The user may copy, distribute, transmit and adapt the work, but must recognise the authors and the South African Journal of Animal Science.
\end{abstract}

\begin{abstract}
The objective of this study was to evaluate the effects of various geometric mean diameters (GMDs) of particles of corn, pelleted soybean meal and a corn-soy mixture in the proportion of $70 \%$ and $30 \%$, respectively, on the nutritional value of the feeds. The study evaluated energy consumption, the contents of apparent metabolizable energy (AME) and $A M E$ corrected for nitrogen balance $\left(A M E_{n}\right)$ and the metabolizability coefficients for broiler chickens at various ages. A total of 540 Cobb 500 male broilers were housed in metabolic cages (experimental units). Trials were performed separately with each feed. A completely randomized design was used with four treatments, namely corn with 573, 636, 851, and $1012 \mu \mathrm{m}$ GMDs; pelleted soybean meal with 538, 550, 665, and $741 \mu \mathrm{m}$ GMDs; and the corn-soy mixture with 627, 658, 893, and $1040 \mu \mathrm{m}$ GMDs. Birds were evaluated on days 1 - 10, $11-20,21-30$, and 31 - 40. Larger GMDs resulted in lower energy consumption. From 1 to 10 days, birds consumed less metabolizable energy than older birds. Birds fed corn from days 1 to 10 had higher metabolizable energy $(P<0.05)$ with increasing GMD up to $1042 \mu \mathrm{m}$. However, the results varied, depending on the feed and its combinations. The use of coarse particles could reduce the costs of grinding, and would have few effects on the metabolizable energy of broiler chickens.
\end{abstract}

Keywords: feed cost, metabolizable energy, rearing phases

"Corresponding author: sanches989@hotmail.com

\section{Introduction}

The metabolizable energy content of feedstuffs is important in meeting the nutritional requirements of broiler chickens. This content can be determined with various methods. It can also be influenced by factors such as age, sex, the amount of feed provided, and the methodology used in the metabolism trials (Kunrath et al., 2010).

Apparent metabolizable energy increases from 0 to 14 days old, and then remains constant (Batal \& Parsons, 2002). A diet based on corn and soybean meal probably increased AME with age owing to the enhanced utilization of starch, fat and protein. The absorptive capacity of the birds could also have been affected by the feed ingredients and the age of the birds (Adeola et al., 2018).

The importance of the physical structure of the diet as a means of improving feed efficiency and live performance has been recognized (Xu et al., 2015). A reduced particle size allows greater interaction of the feed with the digestive enzymes owing to its increased surface area (Chewning et al., 2012). However, a finer particle size could decrease gut peristalsis and increase feed consumption and the rate of passage, thus reducing feed digestibility (Svihus et al., 2002; Pacheco et al., 2013). A coarser feed structure was demonstrated to influence nutrient digestibility and animal live performance positively (Xu et al., 2015). Any reduction in the power used in grinding to reduce the particle size would lower the cost of feed manufacture significantly (Amerah et al., 2008). Thus, information about the relationship of particle size and energy utilization by the birds would make it possible to reduce production costs (Benedetti et al., 2011; Vukmirović et al., 2016).

A very fine GMD of corn - that is, less than $400 \mu \mathrm{m}$ in mash and crumbled feeds - may impair feed intake owing to the presence of dust, which may cause respiratory disorders, contaminate drinking water 
with the feed and increase the water intake and the moisture content of the litter (Brum et al., 1998). However, an optimum particle size has not been well established in the literature. Amerah et al. (2007) concluded a feed particle size between 600 and $900 \mu \mathrm{m}$ was optimal for broiler diets based on maize and sorghum. Parsons et al. (2006) evaluated various particle sizes for corn and found $\mathrm{AME}_{\mathrm{n}}$ was maximized with a particle size of 1042 um. Because a coarser particle size could reduce grinding costs and might increase the $A M E$ and $A M E_{n}$ values for broiler chickens, the objective of this study was to evaluate the effects of various particle sizes of corn, pelleted soybean meal, and a mixture of these ingredients for broiler chickens of different ages.

\section{Material and Methods}

The study was conducted at the Poultry Research Centre of the Experimental Station of Western Parana State University. All procedures that involved birds were approved by the Animal Care and Use Committee of the university (Protocol 027/09).

Three trials were performed to evaluate feeds and their combinations. In the first trial corn was evaluated. In the second trial pelleted soybean meal was assessed, and in the third a mixture of $70 \%$ corn and $30 \%$ pelleted soybean meal was estimated. These ingredients were milled in four batches of $50 \mathrm{~kg}$ and ground through 2-, 4-, 6-, and 8-mm sieves. The hammer mill had a 7.5 horsepower motor, which required three-phase 254 volt electricity. The flow rate of the mill hopper was controlled to maintain the mill at a current intensity of $16 \mathrm{amps}$. At the end of each process, the total time of milling was recorded to calculate the amount of electrical energy used in the process.

The power consumption of the motor during milling was estimated according to this formula (Bhowmick \& Bera, 2008):

$$
C=\sqrt{3} x U x I x \cos \varphi / 1000
$$

where: $\mathrm{C}=$ energy consumption in kilowatt hours,

$\sqrt{ } 3=$ square root of three, because of the three-phase electricity motor,

$\mathrm{U}=$ input voltage,

$\mathrm{I}=$ average amperage,

$\cos \varphi=$ power factor, and

$1000=$ constant to convert watts to kilowatts.

The milling rate $(T / h)$ was determined by dividing the amount milled $(50 \mathrm{~kg})$ by the time, converted from minutes to hours, which resulted in the milling capacity in one hour of working. After milling, an analysis of the GMDs of the feed particles was performed with a granulometric sieve shaker (SP Labor, SP-1100), with 4-, 2-, 1.2-, 0.6-, 0.3-, and 0.15-mm sieves, and a sieve-free compartment (Zanotto \& Bellaver, 1996).

For the metabolic assay, 540 one-day-old male Cobb 500 broiler chickens were obtained from a commercial hatchery. They were raised in a concrete floor covered with pine wood shavings and received a common reference diet (Table 1) based on corn and soybean meal and water ad libitum. When the broiler chickens reached the ages for evaluation, they were transferred to metabolic cages, which were equipped with flow-through type feeders and drinkers. The room temperature was kept within the ideal comfort zone indicated for each phase, according to the values recommended for the strain. The lighting programme consisted of continuous 23 hours light and 1 hour of darkness (30 lux light intensity) throughout the period.

The study was performed in a completely randomized design, with four treatments consisting of the four GMDs. The trials were performed separately for each feed. In the first trial, ground corn with 573,636 , 851 , and $1.012 \mu \mathrm{m}$ GMDs was evaluated. In the second trial pelleted soybean meal with $538,550,665$, and $741 \mu \mathrm{m}$ GMDs was evaluated. Finally, a mixture of $70 \%$ corn and $30 \%$ pelleted soybean meal with 627,658 , 893 , and $1040 \mu \mathrm{m}$ GMDs was assessed. The effects were also evaluated for each particle size. For the prestarter period, ten birds were allocated to each metabolic cage. For the starter period, there were eight birds per cage. For the grower period, there were five birds per cage and for finisher period, there were four birds per cage. The tested feeds replaced the reference diet (Rostagno et al., 2011) at rates of $10 \%, 20 \%, 30 \%$, and $40 \%$.

Each experimental period lasted ten days, with five days to adapt to the diets and cages, and five days to collect excreta (Sibbald \& Slinger, 1963). A galvanized tray was placed under each cage, and the excreta were collected every 12 hours to minimize fermentation. It was then frozen and stored in plastic bags for five days at $-20^{\circ} \mathrm{C}$ until the end of the collection period, when feed intake and the total amount of excreta were measured. The excreta from each cage was defrosted in the plastic bags at room temperature $\left(20^{\circ} \mathrm{C}\right)$ for 12 hours, and homogenized manually, and an aliquot was taken. Each aliquot was weighed and dried in a 
forced-air oven at $55^{\circ} \mathrm{C}$ for 72 hours. Subsequently, the dried excreta were ground in a Wiley-type mill (Star FT-80/2, Fortinox, Piracicaba, SP) using a 1-mm sieve screen and stored for later analysis.

Dry matter (DM) (method 934.01) and crude protein (CP) (method 981.10) were analysed according to AOAC (1990). Gross energy (GE) analysis was conducted using an oxygen calorimetric bomb (IKA C2000, with an accuracy of $0.001^{\circ} \mathrm{C}$ ), and $\mathrm{AME}$ was corrected to zero $\mathrm{N}$ retention $\left(\mathrm{AME}_{n}\right)$ using a factor of 8.22 $\mathrm{kcal} / \mathrm{g}$ (Hill \& Anderson, 1958). The values of $A M E$ and $A M E_{n}$ were calculated according to Matterson et al. (1965).

Table 1 Composition of reference diets (\% as fed) for broiler chickens in various phases of growth

\begin{tabular}{|c|c|c|c|}
\hline \multirow{2}{*}{ Ingredient (g/kg) } & \multicolumn{3}{|c|}{ Phase } \\
\hline & Pre-starter & Starter & Grower and finisher \\
\hline Corn grain & 530.80 & 563.20 & 607.10 \\
\hline Soybean meal $45 \% \mathrm{CP}$ & 398.00 & 361.40 & 311.80 \\
\hline Soybean oil & 26.80 & 35.20 & 42.10 \\
\hline Dicalcium phosphate & 19.30 & 18.30 & 16.90 \\
\hline Limestone & 9.30 & 9.00 & 8.60 \\
\hline Sodium chloride & 5.20 & 5.00 & 4.80 \\
\hline DL-Methionine & 3.50 & 2.60 & 2.50 \\
\hline L- Lysine $\mathrm{HCl}$ & 3.00 & 1.90 & 2.50 \\
\hline L-Threonine & 1.20 & 0.50 & 0.80 \\
\hline Vitamin premix ${ }^{1}$ & 1.00 & 1.00 & 1.00 \\
\hline Choline chloride $60 \%$ & 0.60 & 0.60 & 0.60 \\
\hline Anticoccidial & 0.50 & 0.50 & 0.50 \\
\hline Mineral premix ${ }^{2}$ & 0.50 & 0.50 & 0.50 \\
\hline Antioxidant & 0.20 & 0.20 & 0.20 \\
\hline Avilamycin & 0.10 & 0.10 & 0.10 \\
\hline \multicolumn{4}{|l|}{ Calculated composition $(\mathrm{g} / \mathrm{kg})$} \\
\hline Metabolizable energy (kJ/kg) & 12385 & 12761 & 13180 \\
\hline Crude protein & 230.0 & 214.0 & 197.0 \\
\hline Digestible lysine & 13.630 & 11.890 & 10.990 \\
\hline Digestible methionine & 6.668 & 5.567 & 5.137 \\
\hline Digestible Met+Cis & 9.680 & 8.440 & 7.910 \\
\hline Digestible tryptophan & 2.547 & 2.362 & 2.110 \\
\hline Digestible threonine & 8.860 & 7.730 & 7.140 \\
\hline Calcium & 9.420 & 8.890 & 8.370 \\
\hline Available phosphorus & 4.710 & 4.490 & 4.180 \\
\hline Sodium chloride & 2.240 & 2.180 & 2.080 \\
\hline
\end{tabular}

'Vitamin $\mathrm{A}: 3000 \mathrm{mg}$, vitamin $\mathrm{D}_{3}: 55 \mathrm{mg}$, vitamin $\mathrm{E}: 6000 \mathrm{IU}$, vitamin $\mathrm{B}_{1}: 1.4 \mathrm{~g}$, vitamin $\mathrm{B}_{2}: 4.0 \mathrm{~g}$, vitamin $\mathrm{B}_{6}: 1.8 \mathrm{~g}$, vitamin $\mathrm{B}_{12}: 15,000 \mathrm{mcg}$, pantothenic acid: $8.5 \mathrm{~g}$, vitamin K: 1.4 , folic acid: $0.4 \mathrm{~g}$, nicotinic acid: $25.0 \mathrm{~g}$, selenium: $0.3 \mathrm{~g}$

${ }^{2}$ Iron: $100 \mathrm{~g} / \mathrm{kg}$, copper: $6 \mathrm{~g} / \mathrm{kg}$, manganese: $150 \mathrm{~g} / \mathrm{kg}$, zinc: $100 \mathrm{~g} / \mathrm{kg}$, iodine: $1.5 \mathrm{~g} / \mathrm{kg}$

The data were tested for normality with the Shapiro-Wilk test and subjected to analysis of variance (SAS Institute, Inc., Cary, North Carolina, USA). To evaluate the effects of particle size, linear and quadratic orthogonal polynomials were evaluated. When a polynomial effect was significant, a regression equation was obtained. Tukey's test was used to compare the means for the phases. A probability level of $5 \%$ was regarded as indicating a significant difference. The mathematical model used was:

$$
y_{i j}=\mu+t_{i}+e_{i j}
$$


where: $\gamma_{i j}=$ observation,

$\mu=$ overall mean,

$t_{i}=$ effect of treatment, and

$e_{i j}=$ random residual error.

\section{Results and Discussion}

The GMD values obtained after the grinding process for corn were $573,636,851$ and $1012 \mu \mathrm{m}$ for the 2-, 4-, 6-, and 8-mm sieves, respectively. For the soybean meal, the GMD values were 538, 550, 665 and $741 \mu \mathrm{m}$, and for the corn-soy mixture, the GMD values were 627, 658, 893 and $1040 \mu \mathrm{m}$ (Table 2).

Table 2 Geometric mean diameter of feed particles and energy consumption during milling in various sieves

\begin{tabular}{|c|c|c|c|c|c|c|}
\hline Feed & $\begin{array}{l}\text { Sieve } \\
(\mathrm{mm})\end{array}$ & $\begin{array}{l}\text { GMD } \\
(\mu \mathrm{m})\end{array}$ & Time & $\begin{array}{l}\text { Consump- } \\
\text { tion (kw) }\end{array}$ & $\begin{array}{l}\text { Milling } \\
\text { rate }(\mathrm{t} / \mathrm{h})\end{array}$ & $\begin{array}{c}\text { Consumption per } \\
\text { ton }(\mathrm{kw} / \mathrm{T})\end{array}$ \\
\hline \multirow{4}{*}{ Corn } & 2 & 573 & 7'05" & 0.723 & 0.424 & 14.46 \\
\hline & 4 & 636 & 6'27" & 0.658 & 0.465 & 13.17 \\
\hline & 6 & 851 & 4'28' & 0.456 & 0.672 & 9.12 \\
\hline & 8 & 1012 & 3'31" & 0.359 & 0.853 & 7.17 \\
\hline Mean & & 768 & 5'23" & 0.594 & 0.604 & 10.98 \\
\hline \multirow{4}{*}{$\begin{array}{l}\text { Pelleted soybean } \\
\text { meal }\end{array}$} & 2 & 538 & 4'03" & 0.413 & 0.741 & 8.27 \\
\hline & 4 & 550 & 3'11" & 0.324 & 0.942 & 6.50 \\
\hline & 6 & 665 & 1'43" & 0.175 & 1.748 & 3.50 \\
\hline & 8 & 741 & 1'21" & 0.138 & 2.222 & 2.76 \\
\hline Mean & & 624 & 2'45" & 0.263 & 1.413 & 5.258 \\
\hline \multirow{4}{*}{ Mixture } & 2 & 627 & 6'29" & 0.660 & 0.464 & 13.20 \\
\hline & 4 & 658 & 6'02" & 0.616 & 0.497 & 12.32 \\
\hline & 6 & 893 & 3'32" & 0.361 & 0.849 & 7.21 \\
\hline & 8 & 1040 & 2'31" & 0.257 & 1.192 & 5.14 \\
\hline Mean & & 805 & 4'49" & 0.474 & 0.751 & 9.468 \\
\hline
\end{tabular}

GMD: geometric mean diameter

Corn showed higher milling times, greater energy consumption, and a lower milling rate relative to the other feeds. In contrast, the soybean meal had a lower milling rate in the various sieves, and the corn-soy mixture showed intermediate values, tending to be closer to the corn owing to its composition. The consumption of electrical energy during the milling process ranged from 7.17 to $14.46 \mathrm{kWh} /$ ton for corn, from 2.76 to $8.27 \mathrm{kWh} /$ ton for pelleted soybean meal and from 5.14 to $13.20 \mathrm{kWh} /$ ton for the corn-soy mixture.

For birds of all ages, the mean AME values from those that received corn were higher than $\mathrm{AME}_{\mathrm{n}}$ (Table 3). This effect is usually obtained when the birds are fed ad libitum and nitrogen retention is positive (Kato et al., 2011).

Birds in the pre-starter phase that received corn processed to a GMD of $573 \mu \mathrm{m}$ had smaller $(P<0.05)$ $A M E$ and $A M E_{n}$ values relative to feed consumed (apparent metabolizable energy expressed relative to feed intake (CAME) and $C A M E_{n}$ values, respectively) than older birds (Table 4). There were no differences $(P>0.05)$ in the CAME and $\mathrm{CAME}_{\mathrm{n}}$ values between phases for the finely ground feed. The higher values with older birds may be related to the development of the gastrointestinal tract as a function of increased secretion of bile salts and increased activity of the lipase enzyme, in addition to the more expressive fermentation of structural carbohydrates in the caecum, which improved energy efficiency (Queiroz et al., 2015). 
Table 4 Apparent metabolizable energy and apparent metabolizable energy corrected for nitrogen balance expressed relative to amount of corn consumed as a function of particle size and broiler age

\begin{tabular}{|c|c|c|c|c|c|c|c|c|}
\hline \multirow{2}{*}{ Coefficient } & \multirow{2}{*}{$\begin{array}{l}\text { Age, } \\
\text { days }\end{array}$} & \multicolumn{4}{|c|}{ Geometric mean diameter, $\mu \mathrm{m}$} & \multirow{2}{*}{ SE } & \multicolumn{2}{|c|}{$P$-value } \\
\hline & & 573 & 636 & 851 & 1012 & & Linear & Quadratic \\
\hline \multicolumn{9}{|l|}{ CAME, $\%$} \\
\hline & $1-10$ & $75.33^{b}$ & $78.47^{\circ}$ & $78.53^{\mathrm{b}}$ & $78.69^{b}$ & 0.485 & 0.021 & 0.097 \\
\hline & $11-20$ & $81.98^{\mathrm{a}}$ & $84.83^{\mathrm{a}}$ & $81.79^{\mathrm{ab}}$ & $81.84^{\mathrm{ab}}$ & 0.551 & 0.237 & 0.629 \\
\hline & $21-30$ & $81.84^{a}$ & $81.14^{\mathrm{bc}}$ & $81.01^{\mathrm{ab}}$ & $80.54^{\mathrm{ab}}$ & 0.394 & 0.339 & 0.902 \\
\hline & $31-40$ & $84.58^{\mathrm{a}}$ & $84.25^{\mathrm{ab}}$ & $82.95^{\mathrm{a}}$ & $82.81^{a}$ & 0.322 & 0.103 & 0.505 \\
\hline \multicolumn{9}{|l|}{$\mathrm{CAME}_{n}, \%$} \\
\hline & $1-10$ & $74.19^{\mathrm{b}}$ & $77.13^{\mathrm{b}}$ & $77.02^{\mathrm{b}}$ & $77.59^{\mathrm{b}}$ & 0.463 & 0.015 & 0.184 \\
\hline & $11-20$ & $80.53^{a}$ & $83.12^{\mathrm{a}}$ & $80.12^{\mathrm{ab}}$ & $80.64^{\mathrm{a}}$ & 0.567 & 0.365 & 0.893 \\
\hline & $21-30$ & $80.75^{\mathrm{a}}$ & $80.86^{\mathrm{a}}$ & $80.10^{\mathrm{ab}}$ & $79.87^{\mathrm{ab}}$ & 0.362 & 0.315 & 0.977 \\
\hline & $31-40$ & $82.83^{\mathrm{a}}$ & $82.24^{\mathrm{a}}$ & $81.29^{\mathrm{a}}$ & $81.10^{\mathrm{a}}$ & 0.236 & 0.100 & 0.599 \\
\hline
\end{tabular}

CAME: apparent metabolizable energy expressed relative to feed intake, CAME : apparent metabolizable energy corrected for nitrogen balance expressed relative to feed intake

a,b,c Within a column, means with a common superscript were not different at $P=0.05$

In general the values of CAME and $\mathrm{CAME}_{n}$ for corn processed to 636,851 and $1012 \mu \mathrm{m}$ GMD were lower in the pre-starter phase than in the finisher phase, with the starter and grower phases being intermediate. Similar results were obtained by Kato et al. (2011), who evaluated corn hybrids and found lower $\mathrm{AME}$ and $\mathrm{AME}_{\mathrm{n}}$ values in the pre-starter phase compared with other phases. In the light of this, Freitas et al. (2006) recommended using $A M E_{n}$ in the formulation of starter diets for broiler chicks.

Regression analysis of CAME and $\mathrm{CAME}_{\mathrm{n}}$ values on corn GMDs indicated linear increases $(P<0.05)$ with greater particle size for starter chicks.

$$
\begin{gathered}
C A M E=74.10618+0.00488 G M D\left(R^{2}=0.56\right) \\
C A M E n=72.78208+0.00494 G M D\left(R^{2}=0.56\right)
\end{gathered}
$$

This result may be related to enhanced gizzard activity and improved gastrointestinal tract function with increased particle size (Xu et al., 2015). Feeding coarse particles during the pre-starter phase is important to stimulate the mechanical action of the gizzard when coarser particles are fed subsequently (Rubio et al., 2020). Feeding coarse particles may improve the digestibility of nutrients owing to the lower $\mathrm{pH}$ of the digesta, enhanced peptic digestion, and increased enzyme-substrate interaction from greater retention time (Xu et al., 2015). Similar results were obtained by Amerah et al. (2008), who showed that coarsely ground maize (7-mm hammer mill screen) had positive effects on broiler performance compared with fine grinding (1-mm screen) of pelleted diets.

The results of this study demonstrated that particle sizes up to $1012 \mu \mathrm{m}$ improved energy utilization for birds in the pre-starter phase. However, Jacobs et al. (2010) reported a reduction in metabolizable energy in seven-day old birds fed a particle size of $1387 \mu \mathrm{m}$ compared with smaller particle sizes. Parsons et al. (2006) evaluated the metabolizable energy of corn with various particle sizes They observed a quadratic relationship between particle size and metabolizable energy values, with an intermediate optimum predicted at a particle size of $1042 \mu \mathrm{m}$. Parsons et al. (2006) found greater nitrogen and lysine retention with increases in particle size, and suggested coarse diets. Naderinejad et al. (2016) found improved starch digestibility and AME with greater particle size in pelleted diets, and related these results to increased gizzard weight and reduced gizzard content $\mathrm{pH}$. However, they did not obtain a similar effect of particle size in mash diets.

Particle size had no effect on CAME and $C A M E_{n}$ values for corn in the present study in the starter, grower, and finisher phases. Eyng et al. (2009) evaluated eight cultivars of corn with 656 and $743 \mu \mathrm{m}$ GMDs in broilers from 22 to 32 days old, and obtained CAME of between $72.5 \%$ and $78.49 \%$ and $\mathrm{CAME}_{n}$ between $70.68 \%$ and $76.84 \%$. These values are lower than those found at comparable ages in the present study.

The mean values of AME of the pelleted soybean meals were $11.54 \%, 7.65 \%, 9 \%$ and $10.63 \%$ greater than $\mathrm{AME}_{\mathrm{n}}$ in the pre-starter, starter, grower and finisher phases, respectively (Table 5). The smaller 
difference in the starter phase may have resulted from the higher nitrogen retention of growing birds (Calderano et al., 2010).

Table 5 Apparent metabolizable energy and apparent metabolizable energy corrected for nitrogen balance of pelleted soybean meal as a function of particle size and broiler age

\begin{tabular}{|c|c|c|c|c|c|c|}
\hline \multirow{2}{*}{ Values, $\mathrm{kj} / \mathrm{kg}$} & \multirow{2}{*}{ Age (days) } & \multicolumn{4}{|c|}{ Geometric mean diameter $(\mu \mathrm{m})$} & \multirow{2}{*}{ Average } \\
\hline & & 538 & 550 & 665 & 741 & \\
\hline \multicolumn{7}{|l|}{ AME } \\
\hline & $1-10$ & 9,728 & 9,757 & 9,644 & 9,431 & 9,640 \\
\hline & $11-20$ & 10,774 & 10,322 & 10,799 & 10,564 & 10,615 \\
\hline & $21-30$ & 11,393 & 9,966 & 10,092 & 10,748 & 10,550 \\
\hline & $31-40$ & 12,481 & 12,192 & 12,046 & 10,828 & 11,887 \\
\hline & Average & 11,094 & 10,559 & 10,645 & 10,393 & \\
\hline \multicolumn{7}{|l|}{$\mathrm{AME}_{\mathrm{n}}$} \\
\hline & $1-10$ & 8,678 & 8,598 & 8,473 & 8,360 & 8,527 \\
\hline & $11-20$ & 10,213 & 9,452 & 10,083 & 9,460 & 9,802 \\
\hline & $21-30$ & 10,213 & 9,251 & 9,314 & 9,615 & 9,598 \\
\hline & $31-40$ & 11,150 & 11,025 & 10,648 & 9,673 & 10,624 \\
\hline & Average & 10,064 & 9,582 & 9,630 & 9,277 & \\
\hline
\end{tabular}

AME: apparent metabolizable energy, $\mathrm{AME}_{\mathrm{n}}$ : apparent metabolizable energy corrected for nitrogen balance

Birds that received pelleted soybean meal with 538, 550, and $665 \mu \mathrm{m}$ GMDs had higher values for CAME in the finisher phase (Table 6). In the starter phase, birds fed pelleted soybean meal with a $741 \mu \mathrm{m}$ GMD showed a smaller CAME value, whereas no effects of GMD were found among the other phases. The lower coefficients of digestibility in younger birds might be related to lower enzymatic activity. Digestive capacity was not fully developed in the younger birds and this might limit their utilization of nutrients (Mello et al., 2009). Similar results were obtained by Bertechini et al. (2019), who found greater metabolizable energy values in older birds, which was related to their more developed digestive tracts. Schneiders et al. (2017) evaluated soybean meal (563 $\mu \mathrm{m}$ GMD) for broiler chickens in various phases $(1-8,11-18,31$ - 38, and 41 - 48 days) and found a linear decrease in CAME with age, with values varying from $56.2 \%$ to $51.4 \%$. These authors also evaluated deactivated whole soybean (1588 $\mu \mathrm{m}$ GMD) and obtained increased values with greater age of broilers. Apparent metabolizable energy expressed relative to feed intake varied from $56.8 \%$ to $74.2 \%$, demonstrating differences arising from processing methods.

Regression analysis of CAME and $\mathrm{CAME}_{n}$ values on the GMD of the pelleted soybean meal detected a quadratic effect $(P<0.05)$ for CAME in the grower phase with a minimum value $(54.73 \%)$ estimated at 640 $\mu \mathrm{m}$.

$$
C A M E=262.53280-0.64919 G M D+0.00050702 G M D^{2}\left(R^{2}=0.90\right)
$$

There were also decreasing linear effects on $C A M E$ and $C A M E_{n}$ with the increased particle size $(P$ $<0.05)$ in the finisher phase.

$$
\begin{aligned}
& C A M E=89.17612-0.03740 \times\left(R^{2}=0.68\right) \\
& C^{A M E_{n}}=81.53266-0.03637 \times\left(R^{2}=0.78\right)
\end{aligned}
$$

These results were unexpected. However, the surface area available for enzymatic activity was possibly reduced with a larger particle size (Daveby et al., 1998).

The AME values of the corn-soy mixture were $4.6 \%$ greater relative to $A M E_{n}$ at all ages (Table 7 ). This may have resulted from greater nitrogen retention for deposition in tissues (Generoso et al., 2008). Zang et al. (2009) evaluated diet particle sizes of 953 and $597 \mu \mathrm{m}$ and found greater AME values for a finer particle size compared with a coarser one $(12,510 \mathrm{~kJ} / \mathrm{kg}$ as opposed to $12,138 \mathrm{~kJ} / \mathrm{kg}$, respectively) in birds at 19 to 21 days old and in birds at 42 days old $(12,154$ as opposed to $12,456 \mathrm{~kJ} / \mathrm{kg})$. However, the difference between the AME values at 42 days old was not detected. 
Table 6 Apparent metabolizable energy and apparent metabolizable energy corrected for nitrogen balance expressed relative to the amount of pelleted soybean meal consumed as a function of particle size and broiler age

\begin{tabular}{|c|c|c|c|c|c|c|c|c|}
\hline \multirow{2}{*}{ Values, \% } & \multirow{2}{*}{ Age, days } & \multicolumn{4}{|c|}{ Geometric mean diameter $(\mu \mathrm{m})(\mathrm{GMD})$} & \multirow{2}{*}{ SE } & \multicolumn{2}{|c|}{$P$-value } \\
\hline & & 538 & 550 & 665 & 741 & & Linear & Quadratic \\
\hline \multicolumn{9}{|l|}{ CAME } \\
\hline & $1-10$ & $53.89^{\mathrm{C}}$ & $54.06^{\mathrm{b}}$ & $53.44^{\mathrm{C}}$ & $52.25^{\mathrm{b}}$ & 0.380 & 0.099 & 0.549 \\
\hline & $11-20$ & $59.68^{b}$ & $57.18^{\mathrm{b}}$ & $59.83^{b}$ & $58.51^{a}$ & 0.554 & 0.773 & 0.505 \\
\hline & $21-30$ & $63.13^{\mathrm{b}}$ & $55.21^{\mathrm{b}}$ & $55.90^{\mathrm{C}}$ & $59.55^{\mathrm{a}}$ & 0.862 & 0.202 & 0.001 \\
\hline & $31-40$ & $69.14^{\mathrm{a}}$ & $67.55^{\mathrm{a}}$ & $66.74^{\mathrm{a}}$ & $60.00^{\mathrm{a}}$ & 0.971 & $<0.001$ & 0.006 \\
\hline \multicolumn{9}{|l|}{$\mathrm{CAME}_{\mathrm{n}}$} \\
\hline & $1-10$ & $48.08^{b}$ & $47.63^{\mathrm{b}}$ & $46.94^{\mathrm{C}}$ & $46.31^{b}$ & 0.423 & 0.153 & 0.977 \\
\hline & $11-20$ & $56.59^{\mathrm{a}}$ & $52.36^{\mathrm{b}}$ & $55.85^{\mathrm{a}}$ & $52.41^{\mathrm{a}}$ & 0.922 & 0.483 & 0.384 \\
\hline & $21-30$ & $56.57^{\mathrm{a}}$ & $51.25^{\mathrm{b}}$ & $51.60^{\mathrm{b}}$ & $53.25^{\mathrm{a}}$ & 0.740 & 0.299 & 0.064 \\
\hline & $31-40$ & $61.77^{\mathrm{a}}$ & $61.08^{\mathrm{a}}$ & $58.99^{\mathrm{a}}$ & $53.58^{\mathrm{a}}$ & 0.941 & $<0.001$ & 0.080 \\
\hline
\end{tabular}

CAME: apparent metabolizable energy expressed relative to feed intake, $\mathrm{CAME}_{\mathrm{n}}$ : apparent metabolizable energy corrected for nitrogen balance and expressed relative to feed intake

a,b,c Within a column, means with a common superscript were not different at $P=0.05$

Table 7 Apparent metabolizable energy and apparent metabolizable energy corrected for nitrogen balance in a feed composed of $70 \%$ corn and $30 \%$ soybean meal as a function of particle size and broiler age

\begin{tabular}{|c|c|c|c|c|c|c|}
\hline \multirow{2}{*}{ Values, $\mathrm{kJ} / \mathrm{kg}$} & \multirow{2}{*}{ Age, days } & \multicolumn{4}{|c|}{ Geometric mean diameter, $\mu \mathrm{m}$} & \multirow{2}{*}{ Average } \\
\hline & & 627 & 658 & 893 & 1040 & \\
\hline \multicolumn{7}{|l|}{ AME } \\
\hline & $1-10$ & 12,280 & 12,293 & 12,615 & 12,811 & 12,500 \\
\hline & $11-20$ & 13,075 & 13,221 & 13,372 & 13,631 & 13,325 \\
\hline & $21-30$ & 12,380 & 12,711 & 12,811 & 13,100 & 12,751 \\
\hline & $31-40$ & 14,435 & 14,163 & 14,100 & 13,602 & 14,075 \\
\hline & Average & 13,043 & 13,097 & 13,225 & 13,286 & \\
\hline \multicolumn{7}{|l|}{$\mathrm{AME}_{\mathrm{n}}$} \\
\hline & $1-10$ & 11,657 & 11,807 & 11,979 & 12,142 & 11,896 \\
\hline & $11-20$ & 12,473 & 12,644 & 12,849 & 13,083 & 12,762 \\
\hline & $21-30$ & 11,950 & 12,347 & 12,318 & 12,682 & 12,324 \\
\hline & $31-40$ & 13,615 & 13,426 & 13,380 & 12,958 & 13,345 \\
\hline & Average & 12,424 & 12,556 & 12,632 & 12,716 & \\
\hline
\end{tabular}

AME: apparent metabolizable energy, $\mathrm{AME}_{n}$ : apparent metabolizable energy corrected for nitrogen balance

Birds in the starter phase had lower CAME and $\mathrm{CAME}_{\mathrm{n}}(P<0.05)$ values at all GMDs of the corn-soy mixture than those in the finisher phase (Table 8). Likewise, at 627,658, and $893 \mu \mathrm{m}$ GMD, CAME values $(P$ $<0.05)$ for birds in the grower phase were lower than those in the finisher phase. These effects carried over to the $\mathrm{CAME}_{\mathrm{n}}$ values at 627 and $658 \mu \mathrm{m}$ GMD. Thomas et al. (2008) evaluated various cereal grains, including corn, for birds of various ages and observed that $\mathrm{AME}_{n}$ values at three days old decreased through nine days old and then increased. They posited that these observations were based on the early availability of energy from the yolk sac, changes in the microflora, digestive enzyme availability, endogenous secretions, and inefficiency in mixing of the digesta. 
Table 8 Apparent metabolizable energy and apparent metabolizable energy corrected for nitrogen balance and expressed relative to the amount of $70 \%$ of corn and $30 \%$ of soybean meal mixture consumed as a function of particle size and broiler age

\begin{tabular}{|c|c|c|c|c|c|c|c|}
\hline \multirow{2}{*}{ Age (days) } & \multicolumn{4}{|c|}{ Geometric mean diameter $(\mu \mathrm{m})(\mathrm{GMD})$} & \multirow{2}{*}{ SE } & \multicolumn{2}{|c|}{$P$-value } \\
\hline & 627 & 658 & 893 & 1040 & & Linear & Quadratic \\
\hline \multicolumn{8}{|l|}{ CAME (\%) } \\
\hline $1-10$ & $70.29^{c}$ & $70.35^{c}$ & $72.20^{\mathrm{C}}$ & $73.32^{c}$ & 0.392 & $<0.001$ & 0.932 \\
\hline $11-20$ & $74.83^{b}$ & $75.67^{b}$ & $76.52^{b}$ & $77.18^{\mathrm{a}}$ & 0.475 & 0.109 & 0.861 \\
\hline $21-30$ & $70.87^{c}$ & $72.76^{c}$ & $73.33^{b c}$ & $74.97^{\mathrm{bc}}$ & 0.467 & 0.134 & 0.605 \\
\hline $31-40$ & $82.62^{\mathrm{a}}$ & $81.06^{\mathrm{a}}$ & $80.70^{a}$ & $77.84^{\mathrm{ab}}$ & 0.513 & $<0.001$ & 0.149 \\
\hline \multicolumn{8}{|l|}{$\mathrm{CAME}_{\mathrm{n}}(\%)$} \\
\hline $1-10$ & $66.72^{c}$ & $67.58^{\mathrm{C}}$ & $68.58^{c}$ & $69.49^{b}$ & 0.386 & 0.007 & 0.924 \\
\hline $11-20$ & $71.38^{b}$ & $72.37^{b}$ & $73.53^{\mathrm{ab}}$ & $74.87^{\mathrm{a}}$ & 0.650 & 0.063 & 0.973 \\
\hline $21-30$ & $68.38^{\mathrm{bc}}$ & $70.68^{b}$ & $70.49 b^{c}$ & $72.60^{\mathrm{ab}}$ & 0.432 & 0.079 & 0.287 \\
\hline $31-40$ & $77.93^{\mathrm{a}}$ & $76.85^{\mathrm{a}}$ & $76.60^{\mathrm{a}}$ & $74.17^{\mathrm{a}}$ & 0.464 & 0.003 & 0.234 \\
\hline
\end{tabular}

${ }^{a, b, c}$ Within a column, means with a common superscript were not different at $P=0.05$

The regression of CAME and $C A M E_{n}$ values on GMD of the mixed ration indicated a linear increase for birds in the pre-starter phase:

$$
\begin{aligned}
& C A M E=65.93050+0.00720 G M D(R 2=0.71) \\
& C A M E_{n}=64.44134+0.00459 G M D(R 2=0.48)
\end{aligned}
$$

There was no effect $(P>0.05)$ of GMD on CAME and $\mathrm{CAME}_{\mathrm{n}}$ in the starter and grower phases. However, the birds in the final phase showed a linear decrease in CAME and $C A M E_{n}$ with increased GMD:

$$
\begin{gathered}
C A M E=87.30396-0.00868 \times(R 2=0.76) \\
C A M E n=81.70721-0.00688 \times(R 2=0.59)
\end{gathered}
$$

Particle sizes greater than $1000 \mu \mathrm{m}$ could adversely influence the performance of younger birds because they have lower gizzard capacity to break the larger particles (Amerah et al. 2007). In the present study, and contrary to Amerah et al. (2007), the corn-soy mixture with GMD of $1040 \mu \mathrm{m}$ improved the CAME and $\mathrm{CAME}_{\mathrm{n}}$ values in birds from 1 to 10 days old. Similar results were obtained by Parsons et al. (2006), who evaluated various particle sizes in broiler chickens at 28 days old, and obtained a linear increase in nitrogen and nutrient retention with increasing particle size. However, they observed reduced bird performance and energy metabolism when the particle size exceeded $1042 \mu \mathrm{m}$.

\section{Conclusion}

The larger particle sizes evaluated in this study resulted in benefits because of the lower energy cost of grinding. However, when one considers all phases and feeds, few differences occurred in the metabolizable energy values. Metabolizable energy was generally higher for older birds.

\section{Authors' Contributions}

RF, CS and RAS collected the data for this study. ASA, PLO, CE, JB and RF conducted the statistical analyses, collaborated in interpretation of the results, wrote the initial draft of this manuscript, and finalized the manuscript. RVN and PCP developed the original hypothesis, designed the experiments, and collaborated in interpreting the results. The authors have read and approved the finalized manuscript.

\section{Conflict of Interest Declaration}

The authors declare there is no conflict of interest. 


\section{References}

Adeola, O., Anwar, M.N., Abdollahi, M.R. \& Ravindran, V., 2018. Age-related energy values of meat and bone meal for broiler chickens, Poultry Sci. 97, 2516-2524. DOI: 10.3382/ps/pey100

Amerah, A.M., Ravindran, V., Lentle, R.G. \& Thomas, D.G., 2007. Feed particle size: Implications on the digestion and performance of poultry. World Poultry Sci. J. 63, 439-445. DOI: $10.1017 /$ s0043933907001560

Amerah, A.M., Ravindran, V., Lentle, R.G. \& Thomas D.G., 2008. Influence of feed particle size on the performance, energy utilization, digestive tract development, and digesta parameters of broiler starters fed wheat- and cornbased diets. Poult. Sci. 87, 2320-2328. DOI: 10.3382/ps.2008-00149

AOAC, 1990. Official methods of analysis. 15th edition. Association of Official Analytical Chemists, Arlington, VA, USA. P. 125.

Batal, A.B., \& Parsons, C.M., 2002. Effects of age on nutrient digestibility in chicks fed different diets. Poult. Sci. 81, 400407. DOI: $10.1093 / \mathrm{ps} / 81.3 .400$

Benedetti, M.P., Sartori, J.R., Carvalho, F.B., Pereira, L.A., Fascina, V.B., Stradiotti, A.C., Pezzato, A.C., Costa, C. \& Ferreira, J.G., 2011. Corn texture and particle size in broiler diets. Braz. J. Poult. Sci. 13, 227-234.

Bertechini, A.G., Kato, R.K., Freitas, L.F.V., Castro, R.T.C. \& Mazzuco, H., 2019. Metabolizable energy values of soybean meals and soybean oil for broilers at different ages. Acta Sci. Anim. Sci. 41, e44540. DOI: 10.4025/actascianimsci.v41i1.44540

Bhowmick, M.S. \& Bera, S.C., 2008. Study the Performances of induced fans and design of new induced fan for the efficiency improvement of a thermal power plant. Colloq. and Third Int. Conf. on Information Systems Security, Kharagpur, India. Pp. 1-5.

Brum P.A.R., Zanotto D.L. \& Guidoni, A.L., 1998. Corn granulometry in mashed rations for broilers: Technical instruction for the poultry farmer. Concórdia, EMBRAPA-CNPSA. P. 2 (in Portuguese).

Calderano, A.A., Gomes, P.C., Albino, L.F.T., Rostagno, H.S., Souza, R.M. \& Mello, H.H.C., 2010. Chemical and energetic composition vegetable protein feeds determined in birds of different ages. Rev. Bras. Zootec. 39, 320326 (in Portuguese).

Chewning, C.G., Stark, C.R. \& Brake, J., 2012. Effects of particle size and feed form on broiler performance. J. Appl. Poultry Res. 21, 830-837. DOI: 10.3382/japr.2012-00553

Daveby, Y.D., Razdan, A.\& Aman, P., 1998. Effect of particle size and enzyme supplementation of diets based on dehulled peas on the nutritive value for broiler chickens. Anim. Feed Sci. Tech. 74, 229-239. DOI: 10.1016/S03778401(98)00174-6

Eyng, C., Nunes, R.V., Pozza, P.C., Pozza, M.S.S., Nunes, C.G.V., Navarini, F.C., Silva, W.T.M. \& Appelt, M.D., 2009. Chemical composition and energetic values of different corn cultivar for poultry. Rev. Bras. Saúde Prod. Anim. 10, 60-72 (in Portuguese, English abstract).

Freitas, E.R., Sakomura, N.K., Ezequiel, J.M.B., Neme R. \& Mendonça, M.O., 2006. Metabolizable energy of feeds on diet formulation for broilers. Pesqui. Agropecu. Bras. 41, 107-115 (in Portuguese, English abstract).

Generoso, R.A.R., Gomes, P.C., Rostagno, H.S., Albino, L.F.T., Barreto, S.L.T. \& Brumano, G., 2008. Chemical and energy composition of some feeds for broiler chicks and two ages. Rev. Bras. Zootecn. 37, 1251-1256 (in Portuguese, English abstract).

Hill, F.W. \& Anderson, D.L., 1958. Comparison of metabolizable energy and productive energy determinations with growing chicks. J. Nutr. 64, 587-603. DOI: 10.1093/jn/64.4.587

Jacobs, C.M., Utterback, P.L. \& Parsons, C.M., 2010. Effects of corn particle size on growth performance and nutrient utilization in young chicks. Poult. Sci., 89, 539-544. DOI: 10.3382/ps.2009-00434

Kato, R.K., Bertechini, A.G., Fassani, E.J., Brito, J.A.G. \& Castro, S.F., 2011. Metabolizable energy of corn hybrids for broiler chickens at different ages. Ciênc. Agrotec. 35, 1218-1226.

Kunrath, M.A., Kessler, A.D.M., Ribeiro, A.M.L., Vieira, M.D.M., Silva, G.L.D. \& Peixoto, F., 2010. Evaluation methodologies of nutritional value of defatted rice bran for swine. Pesq. Agropec. Bras. 45, 1172-1179 (in Portuguese, English abstract). DOI: 10.1590/S0100-204X2010001000017

Matterson, L.D., Potter, L.M., Stutz, M.W. \& Singsen, E.P., 1965. The metabolizable energy of feed ingredients for chickens. Res. Rep. Conn. Agric. Exp. Stn. 7, 11-14.

Mello, H.H.C., Gomes, P.C., Rostagno, H.S., Albino, L.F.T., Souza, R.M. \& Calderano, A.A., 2009. Metabolizable energy values of some feeds obtained from birds of different ages. Ver. Bras. Zootec. 38, 863-868 (in Portuguese, English Abstract).

Naderinejad, S., Zaefarian, F., Abdollahi, M.R., Hassanabadi, A., Kermanshahi, H. \& Ravindran, V., 2016. Influence of feed form and particle size on performance, nutrient utilisation, and gastrointestinal tract development and morphometry in broiler starters fed maize-based diets. Anim. Feed Sci. Tech. 215, 92-104. DOI: 10.1016/j.anifeedsci.2016.02.012

Pacheco, W.J., Stark, C.R., Ferket, P.R. \& Brake, J., 2013. Evaluation of soybean meal source and particle size on broiler performance, nutrient digestibility, and gizzard development. Poult. Sci. 92: 2914-2922. DOI: 10.3382/ps.2013-03186

Parsons, A.S., Buchanan, N.P., Blemings, K.P., Wilson, M.E. \& Moritz, J.S., 2006. Effect of corn particle size and pellet texture on broiler performance in the growing phase. J. Appl. Poultry Res. 15, 245-255. DOI: 10.1093/japr/15.2.245

Queiroz, A.P.L.B., Carvalho, C.M.C., Martins, J.M.D.S., Litz, F.H. \& Fernandes, E.D.A., 2015. Chemical composition, metabolizable energy and digestibility of nitrogen and ether extract from corn and sorghum samples for broiler chickens at different ages. Vet. Not. 21, 30-40 (in Portuguese). DOI: 10.14393/VTv21n1a2015.121 
Rostagno, S.H., Albino, L.F.T., Donzele, J.L., Gomes, P.C., Oliveira, R.F., Lopes, D.C., Ferreira, A.S., Barreto, S.L.T. \& Euclides, R.F., 2011. Brazilian tables for poultry and swine: Feed composition and nutritional requirements. Third edition. Viçosa, MG (in Portuguese).

Rubio, A.A., Hess, J.B., Berry, W.D., Dozier III, W.A. \& Pacheco, W.J., 2020. Effects of corn particle size on broiler performance during the starter, grower, and finisher periods. J. Appl. Poult. Res. 29, 352-361. DOI: 10.1016/j.japr.2019.11.009

Schneiders, J.L., Nunes, R.V., Schöne, R.A., Frank, R., Savoldi, T.L., Tsutsumi, C.Y., Scherer, C. \& Castilha, L.D., 2017. Energy coefficients of plant foods for broiler chickens at different ages. Semina: Ciênc. Agrár. 38, $2119-2128$. DOI: $10.5433 / 1679-0359.2017 \mathrm{v} 38 \mathrm{n} 4 \mathrm{p} 2119$

Sibbald, I.R. \& Slinger, S.J., 1963. A biological assay for metabolizable energy in poultry feed ingredients together with findings which demonstrate some of the problems associated with evaluation of fats. Poultry Sci. 42, 13-25. DOI: 10.3382/ps.0420313

Svihus, B., Hetland, H., Choct, M. \& Sundby, F., 2002. Passage rate through the anterior digestive tract of broiler chickens fed on diets with ground and whole wheat. Br. Poult. Sci. 43, 662-668. DOI: $10.1080 / 0007166021000025037$

Thomas, D.V., Ravindran V. \& Ravindran G., 2008. Nutrient digestibility and energy utilization of diets based on wheat, sorghum or maize by the newly hatched broiler chick. Brit. Poultry Sci. 49, 429-435. DOI: $10.1080 / 00071660802213467$

Vukmirović, D.M., Lević, J.D., Fišteš, A.Z., Čolović, R.R., Brlek, T.I., Čolović, D.S. \& Đuragić, O.M., 2016. Influence of grinding method and grinding intensity of corn on mill energy consumption and pellet quality. Hem. Ind. 70, 67-72. DOI: 10.2298/HEMIND141114012V

Xu, Y., Stark, C.R., Ferket, P.R., Williams, C. M., Pacheco, W. J. \& Brake, J., 2015. Effect of dietary coarsely ground corn on broiler live performance, gastrointestinal tract development, apparent ileal digestibility of energy and nitrogen, and digesta particle size distribution and retention time. Poultry Sci. 94, 53-60. DOI: 10.3382/ps/peu015

Zang, J.J., Piao, X.S., Huang, D.S., Wang, J.J., Ma, X. \& Ma, Y.X., 2009. Effects of feed particle size and feed form on growth performance, nutrient metabolizability and intestinal morphology in broiler chickens. Asian-Austral. J. Anim. Sci. 22, 107-112. DOI: 10.5713/ajas.2009.80352

Zanotto, D.L. \& Bellaver, C., 1996. Method of determining the particle size of ingredients for use in pig and poultry feed. Technical release 215. EMBRAPA-CNPSA, Concórdia, SC. (in Portuguese). 